Similarly, there was a strong association between seroprevalence and type of cluster. Behavioural risk factors, such as the proportion of people in each cluster reporting two or more sexual partners, external travel, and injections, were correlated with higher seroprevalence in women but not in men (table I). Thus residence in an agricultural community reduces the risk of HIV infection, but for women the protective effect of rural residence may be countered by factors such as community levels of external travel and multiple sex partners, behaviours which are predominantly reported by men. The data suggest that the introduction of HIV into rural communities may be largely associated with male behaviour, including the infection with HIV during travel outside the cluster and contact with multiple partners on return. Levels of education, soçioeconomic status, and knowledge of AIDS were higher in the trading centres and trading villages than in the agricultural villages. The pattern of HIV infection is thus not due to greater availability of information or services in low prevalence rural communities.

Further prospective studies will permit estimates of patterns of HIV infection and transmission. For the present, categorising rural Ugandan communities into three strata provides a useful approach to identify high risk communities by their characteristics and potentially to develop targeted interventions permitting more effective use of limited resources. Trading centres and rural trading villages should be considered targets for intensive preventive interventions both for their benefit and potentially to prevent spread of infection from these high prevalence communities to neighbouring lower prevalence rural areas.

We thank Dr S Okware, Ugandan AIDS Control Programme; Drs Sampala, B Biryawaho, R Downing, Ugandan Virus Research Institute; Dr S Berkley, Rockefeller Foundation; Drs Z Stein, M Begg, Columbia University; Ms M F
Lafontaine; Dr R H Gray, Mr M Emerson, Johns Hopkins University; and Dr J Kaplan, Centers for Disease Control. This study was supported by National Institute of Allergy and Infectious Diseases, National Institutes of Health (R01A129314-01); Research Division, Office of Population, United States Agency for International Development (cooperative agreement DPE-3030-A-00-4049); Rockefeller Foundation.

1 N'Galy B, Ryder RW, Bila K, Mwandagalirwa K, Colebunders RL, Francis $H$, et al. Human immunodeficiency virus infection among employees in an African hospital. N Engl F Med 1988;319:1123-7.

2 Kreiss JK, Koech D, Plummer FA, Holmes KK, Lightfoote M, Piot P, et al. AIDS virus infection in Nairobi prostitutes: spread of the epidemic to east Africa. $N$ Engl I Med 1986;314:414-8

3 Piot P, Plummer FA, Rey MA, Ngugi EN, Rouzioux C, Ndinya-Achola JO et al. Retrospective seroepidemiology of HIV in Nairobi populations. Infect Dis 1987;155:1108-12.

4 De Cock KM, Porter A, Odehouri K, Barrere B, Moreau J, Diaby L, et al. Rapid emergence of AIDS in Abidjan, Ivory Coast. Lancet 1989;ii:408-11.

Dolmans WMV, van Loon AM, van den Akker R, Mulder DW, Shau JF, Mbena E, et al. Prevalence of HIV-1 antibody among groups of patients and healthy subjects from a rural and urban population in the Mwanza region, Tanzania. AIIDS 1989;3:297-9.

6 Denis F, Barin F, Gershy-Damet G, Rey JL, Luhillier M, Mounier M, et al. Prevalence of human T-lymphotrophic retroviruses type III (HIV) and type V in Ivory Coast Lancet 1987; i:408-11.

7 de Lalla F, Rizzardini G, Santoro D, Galli M. Rapid spread of HIV infection in a rural district in central Africa. AIDS 1988;2:317.

8 Killewo J, Nyamurekunge K, Sandstrom A, Bredberg-Raden U, Wall S, Mhalu F, Biberfeld G. Prevalence of HIV-1 infection in the Kagera region of Tanzania: a population-based study. AIDS 1990;4:1081-5.

9 Naamara W, Plummer F. Cross sectional study of HIV infection in SW Uganda. In: Proceedings of the second international conference on AIDS in Africa, Naples, 1988. Abstract 37.

10 Carswell JW. HIV infection in healthy persons in Uganda. AIDS 1987; 223-7.

11 Hosmer DW, Lemeshow S. Applied logistic regression. New York: John Wiley and Sons, 1989.

12 Cochran WG. Sampling techniques. 3rd ed. New York: John Wiley and Sons, 1977.

13 Serwadda D, Mugerwa RD, Sewankambo NK, Lwegaba A, Carswell JW Dirva GB. Slim disease, a new disease in Uganda and its association with HTLV-III infection. Lancet 1985;ii:849-52.

14 Wilcox RR. Venereal diseases in the Pacific Islands: Papua New Guinea Br f Vener Dis 1980;56:277-81.

15 Plorde DS. Sexually transmitted disease in Ethiopia: Social factors contributing to their spread and implications for developing countries. $\mathrm{Br} \mathcal{F}$ Vener $D i$ to their spread and

16 Carswell JW, Lloyd G, Howells J. Short communication: prevalence of HIV-I in east African lorry drivers. AIDS 1989;3:759-61.

Accepted 30 August 1991

\title{
Serum sialic acid concentration and smoking: a population based study
}

\section{Centre for Public Health \\ Research, S-651 82 \\ Karlstad, Sweden \\ Gunnar Lindberg, MD, senior \\ physician}

\section{Department of \\ Community Health}

Sciences, University of

Lund, Malmö, Sweden

Lennart Råstam, MD, senior

lecturer in family medicine

Bo Gullberg, MA, senior

lecturer in medical statistics

\section{Radiumhemmet,}

Karolinska Hospital,

Stockholm, Sweden

Gunnar A Eklund, PHD,

professor of epidemiology,

department of cancer

epidemiology

Sven Törnberg, MD,

consultant oncologist,

department of general

oncology

Correspondence to:

Dr Lindberg.

B.11: 1991:303:1306-7

\section{Gunnar Lindberg, Lennart Råstam, Bo Gullberg, Gunnar A Eklund, Sven Törnberg}

We recently showed that the serum sialic acid concentration predicts mortality from cardiovascular diseases among men and women independently of blood pressure, total cholesterol concentration, and body mass index. ${ }^{1}$ The relation between sialic acid concentration and mortality from cardiovascular disease is unclear. Smoking is a possible confounder that has not been investigated. We therefore investigated whether smoking habits influence the sialic acid concentration.

\section{Subjects, methods, and results}

The Värmland survey, in which sialic acid concentrations were measured in 97468 subjects in 1962-5, has been described.' : The methods of Hess et al and Svennerholm were used to determine the sialic acid concentration in 1962-3 and 1963-5, respectively. ${ }^{3+}$ In 1963 a Swedish national postal survey of smoking habits was undertaken. ${ }^{5}$ A random sample of roughly $1 \%$ of the adult Swedish population, stratified for age, was asked about their present and past smoking habits. The response rate was $94 \%$.
For the present study we used an algorithm based on the grams of tobacco consumed in 1963 as cigarettes, cigars, or pipe tobacco to quantify the amount smoked. We defined smokers as those who had reported smoking cigarettes, cigars, or a pipe daily. We defined non-smokers as those who had never smoked. Computerised records from subjects who participated in both studies were linked by using the personal identification number. We used analysis of variance and analysis of covariance for statistical testing. Significance was assumed at $\mathrm{p}<0.05$.

A total of 518 men and 504 women participated in both the Värmland survey and the survey of smoking habits in Sweden. Altogether 220 men and 62 women were regular smokers, and 116 men and 383 women had never smoked.

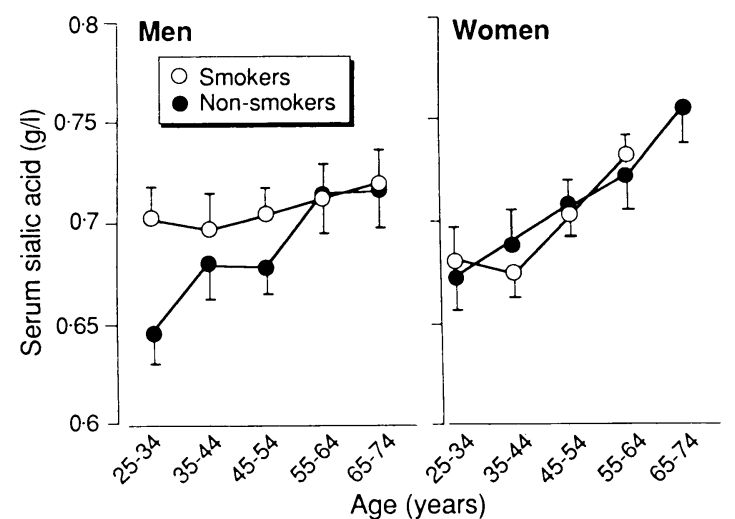

Serum sialic acid concentration in men and women according to smoking habit and age 
After adjustment for age the partial correlation coefficients between the amount of tobacco consumed daily and the sialic acid concentrations were 0.10 $(p=0.04)$ for men and $0.01(p=0.90)$ for women (nonsmokers were assumed to consume $0 \mathrm{~g}$ ). Among men the sialic acid concentration adjusted for age was 0.69 $\mathrm{g} / \mathrm{l}$ in non-smokers and $7 \cdot 1 \mathrm{~g} / \mathrm{l}$ in smokers $(\mathrm{p}=0.09)$. The corresponding figures for women were 0.71 and $0.71 \mathrm{~g} / 1$ respectively $(\mathrm{p}=0.96)$.

There was a significant positive correlation between age and sialic acid concentration in male non-smokers and in female smokers and non-smokers. Young male smokers, however, had almost the same sialic acid concentration as old male smokers (figure). Consequently, a decreasing difference in sialic acid concentration between male smokers and non-smokers was observed with increasing age, but this trend was not significant $(p=0 \cdot 15)$.

\section{Comment}

The correlation between smoking habits and sialic acid concentration is probably low enough to rule out smoking as a confounder in the relation between sialic acid concentration and mortality from cardiovascular disease. We have already shown that sialic acid concentration increases with age in both men and women. ' In this study this trend was absent in male smokers, who from a young age had a sialic acid concentration equal to that in older male smokers. A tentative explanation for the difference found between the sexes may be that in young men smoking initiates or aggravates atherosclerosis, which increases the sialic acid concentration. In premenopausal women, who are less vulnerable to atherosclerosis this process could be less important.

1 Lindberg G, Eklund GA, Gullberg B, Răstam L. Serum sialic acid concentration Allmänna Förlaget, 1971

3 Hess EL, Coburn AF, Bates C, Murphy P. A new method for measuring sialic acid levels in serum and its application to rheumatic fever. $\mathcal{f}$ Clin Invest 1957;36:449-55.

4 Svennerholm L. Quantitative estimation of sialic acids. Biochem Biophys Acta 1957;24:604-11.

5 Carstensen J, Pershagen G, Eklund G. Mortality in relation to cigarette and pipe smoking: 16 years' observation of 25000 Swedish men. I Epidemiol Community Health 1987; 41:166-72.

(Accepted 4 fuly 1991) and 27692 women. $B M F 1991 ; 302: 143-6$.

2 National Board of Health and Welfare. The Varmland survey. Stockholm:

\section{Surveillance of antibiotic resistance in clinical isolates of Neisseria gonorrhoeae}

\author{
C A Ison, N S Branley, K Kirtland, \\ C S F Easmon
}

\section{Department of Medical Microbiology, St Mary's Hospital Medical School, London W2 1PG \\ C A Ison, PHD, lecturer \\ N S Branley, BSC, research assistant \\ K Kirtland, FIMLs, deputy laboratory manager \\ C S F Easmon, MD, professor}

Correspondence to:

Dr Ison.

BMF 1991;303:1307

\begin{tabular}{|c|c|}
\hline \multicolumn{2}{|c|}{$\begin{array}{l}\text { In vitro susceptibility of } 896 \\
\text { consecutive gonococcal isolates to } \\
\text { ciprofloxacin and penicillin }\end{array}$} \\
\hline $\begin{array}{l}\text { Antibiotic } \\
\text { susceptibility } \\
\text { (minimum } \\
\text { inhibitory } \\
\text { concentration) } \\
\text { (mg/l) }\end{array}$ & $\begin{array}{l}\text { No }(\%) \text { of } \\
\text { isolates }\end{array}$ \\
\hline \multicolumn{2}{|l|}{ Ciprofloxacin: } \\
\hline$\leqslant 0.008$ & $840(93 \cdot 8)$ \\
\hline $0.015-0.03$ & $51(5 \cdot 7)$ \\
\hline $0 \cdot 06-0 \cdot 12$ & $2(0 \cdot 2)$ \\
\hline$>0 \cdot 12$ & $3(0 \cdot 3)$ \\
\hline \multicolumn{2}{|l|}{ Penicillin: } \\
\hline$\leqslant 0.06$ & $452(50 \cdot 4)$ \\
\hline $0 \cdot 12-0 \cdot 5$ & $379(42 \cdot 3)$ \\
\hline$\geqslant 1 \cdot 0$ & $65(7 \cdot 3)$ \\
\hline
\end{tabular}

Gonococci are becoming increasingly resistant to antimicrobial agents such as penicillin, tetracycline, the newer cephalosporins, and spectinomycin. Fluorinated quinolones such as ciprofloxacin provide an effective alternative treatment for gonorrhoea. Recent evidence of reduced gonococcal susceptibility to these agents in vitro, coupled with reports of failures of clinical treatment with quinolones, ${ }^{1}$ prompted us to determine the prevalence of reduced susceptibility to ciprofloxacin and penicillin in gonococci isolated from patients attending the sexually transmitted diseases clinic at this hospital.

\section{Materials, methods, and results}

We monitored susceptibility of 896 consecutive isolates of Neisseria gonorrhoeae to ciprofloxacin and The medium used was diagnostic sensitivity agar (Oxoid) supplemented with $1 \%$ IsoVitaleX and 5\% lysed horse blood (Tissue Culture Services). The inoculum was $10^{5}$ colony forming units, and the test cultures were read after 48 hours' incubation at $36^{\circ} \mathrm{C}$ in $6 \%$ carbon dioxide. World Health Organisation control strains A-E were included in each run. Penicillin was used at concentrations of $0.06 \mathrm{mg} / 1$ and $0.5 \mathrm{mg} / \mathrm{l}$. Isolates that grew at both concentrations were defined as penicillin resistant (minimum inhibitory concentration $\geq 1.0 \mathrm{mg} / \mathrm{l}$ ), those that grew only at $0.06 \mathrm{mg} / \mathrm{l}$ as concentration $>0.06 \mathrm{mg} / \mathrm{l} \leq 0.5 \mathrm{mg} / \mathrm{l}$ ) and those that grew at neither concentration as penicillin sensitive (minimum inhibitory concentration $\leq 0.06 \mathrm{mg} / \mathrm{l}$ ). The categories that define reduced susceptibility to ciprofloxacin are unknown, and therefore after preliminary screening we chose three concentrations for incorporapenicillin with the agar dilution breakpoint technique. showing intermediate resistance (minimum inhibitory tion into the medium: $0 \cdot 008 \mathrm{mg} / \mathrm{l}, 0.03 \mathrm{mg} / \mathrm{l}$, and $0 \cdot 12$ $\mathrm{mg} / \mathrm{l}$.

The table shows the in vitro susceptibility of the 896 isolates to penicillin and ciprofloxacin. The results for penicillin show the expected bimodal distribution whereas those for ciprofloxacin suggest that reduced susceptibility to the antibiotic is not yet a major problem. In only three isolates was the minimum inhibitory concentration $>0.12 \mathrm{mg} / \mathrm{l}$, in the range associated with the few reported treatment failures. ${ }^{13}$

\section{Comment}

There is as yet little information about the relation between in vitro gonococcal susceptibility to ciprofloxacin and clinical efficacy. With other Gram negative species a minimum inhibitory concentration of $1-2 \mathrm{mg} / \mathrm{l}$ is usually equated with clinical resistance. However, as such infections are usually treated with multiple dosage regimens given over several days they cannot be readily compared with gonorrhoea treated with a single dose of ciprofloxacin.

There is no evidence of plasmid mediated ciprofloxacin resistance in gonococci. Resistance probably results from either a mutation in the gene controlling DNA gyrase or a permeability barrier to ciprofloxacin in the cell envelope. ${ }^{4}$ Given the lack of knowledge about the genetic control and prevalence of reduced $\mathrm{N}$ susceptibility to ciprofloxacin in $N$ gonorrhoeae, we $\frac{D}{D}$ need to monitor the susceptibility of gonococcal isolates and hence obtain more data on the association $N$ between in vitro susceptibility and clinical efficacy. The three concentration agar incorporation breakpoint method provides a simple method of screening ciprofloxacin susceptibility patterns without the need for full testing of minimum inhibitory concentrations.

We thank Pat Woodford for technical help. The work was funded by Bayer UK.

Gransden WR, Warren C, Phillips I. 4-Quinolone-resistant Neisseria gonor- O rhoeae in the United Kingdom. F Med Microbiol 1991;34:23-7.

2 Gill MJ, Ison CA. Susceptibility testing of Neisseria gonorrhoeac to penicillin and spectinomycin in a diagnosic lahoratury. J Clin Pathol 1988:41:978-82. Jephcott AE, Turner A. Ciprofloxacin resistance in gonococci. Lancet 1990;335: 165

4 Lewin CS, Allen RA, Avmes SGB. Potential mechanisms of resistance to the modern fluorinated 4-quinolones. 7. Med Microbiol 1990;31:153-62.

(Accepted 17 fuly 199l)

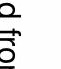
(1)

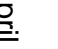

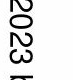

